\title{
ROMANIAN TRAVELLERS TO ENGLAND IN THE NINETEENTH CENTURY. NATIONAL SPECIFICITY IN ION CODRU- DRĂGUȘANU'S TRAVEL ACCOUNTS
}

\author{
Mihaela Culea \\ "Vasile Alecsandri" University of Bacău, Romania \\ Andreia-Irina Suciu \\ "Vasile Alecsandri" University of Bacău, Romania
}

\section{Introduction}

A theoretical discussion of related concepts from the semantic field of travelling should take into consideration such synonymous terms as voyager, tourist, passenger, journeyer, explorer, discoverer, tourer, tripper, globetrotter, holidaymaker, wayfarer, excursionist, sightseer, surveyor, visitor, or wanderer, as listed indiscriminately by the Oxford Dictionary online. ${ }^{1}$ However, the careful examination of the meanings of the most commonly used terms from the series reveals significant differences.

The most general term from the series, traveller, now has the general meaning of a person who travels, especially routinely. ${ }^{2}$ One distinction which requires mentioning with relation to the act of travelling is that between journeys and voyages. Thus, be it on land, water or in the air, we can encounter explorers who during such expeditions travel to unknown or unfamiliar places in order to examine or investigate, especially systematically, so it is their contribution to scientific knowledge that predominates. Journeys involve travelling from one place to another, whereas voyages represent long journeys to distant places especially by water or air. Pilgrims travel to sacred places out of religious piousness and their experience constitutes a religious practice, so their travels acquire spiritual connotations. In recent times, in the context of globalization or of the increasingly promoted borderless Europe, the impetus of migration from south-east European

\footnotetext{
${ }^{1}$ http://www.oxforddictionaries.com/definition/english-thesaurus/traveller, accessed October 5, 2014.
}

${ }^{2}$ http://www.oxforddictionaries.com/definition/english/traveller, accessed October 5, 2014. 
states to western states has given a new configuration to the continent and it is mainly dictated by economic reasons, so a migrant often travels to another country to find work and live there, usually temporarily.

If we consider the distinction between the terms traveller and tourist, we observe that the shift from the condition of a traveller to that of a tourist is a historically dependent phenomenon and the terms define two states as well as two different historical categories projected against key historical and socio-cultural phenomena. Historically speaking, the signification attached to the travelling activity has also changed and, after 1939, the death of travel and the emergence of tourism could be identified, as Paul Fussell argues (in Abroad, 1972, apud Culler 1990). Daniel Boorstin (1992) claims that the decline of travelling occurred much earlier, after the middle of the nineteenth century, as a result of improved transportation and infrastructure, the proliferation of mass transportation and all the other measures that made travelling become inexpensive, safe, accessible and pleasurable. From this perspective, the system of tourism is inevitably connected with the capitalist society and many of its features. In the contemporary postmodern period, having changed from "an activity" into a "commodity" (ibid.), what we may designate as touristic travelling responds to the calls of the entertainment culture and the culture industry in many ways. A "lost art", the experience of travelling is very much different nowadays insofar as "it has become diluted, contrived, prefabricated", as pointed out by Boorstin (ibid.: 79).

As far as the condition of being a traveller is concerned, the traveller is meditative, self-reflexive, thoughtful, even sober, intellectually and aesthetically curious, analytical and participative. A traveller himself, N. Iorga (1980) outlined some of the most prominent features of a traveller's personality, as follows: communicative, intellectually active, erudite, with an adventurous spirit, curious, sensitive, aesthetically responsive, self-reflexive, inquisitive, well-informed (the traveller must possess substantial knowledge of the places he intends to visit, so that he can perceive the essential aspects of that culture, in point of both material and spiritual nature), an acute observer with a certain degree of maturity. On the other hand, since he is travelling or visiting a place for pleasure and out of curiosity, a tourist's effort, interests and goals are very much unlike those of a traveller in the conventional sense mentioned above.

In effect two different social practices, they also define two different types of attitude. Commonly, the traveller's activity is related primarily to work or some kind of activity involving effort, whereas the tourist is "a pleasure-seeker" who travels in order to see, admire, gaze, experience nothing but "pseudo-events" (Boorstin 1992: 79) and entertain himself. The traveller is active, always moving 
forward, observing, looking for knowledge, adventure, and experience (ibid.: 85). The tourist is passive and waits for exciting things to happen to him and pleasing things "to be done to him and for him" (ibid.). Tourists go sight-seeing so as to satiate their curiosity and appetite for pleasurable things and encounters. Travelling is thus a complex activity: as an experience and an undertaking, it actively engages the traveller in his intellectual, spiritual or aesthetic pursuits because it is also a means of understanding and explaining the world and this undertaking involves work. From another perspective, given that, metaphorically speaking, travelling means any itinerary undertaken in the realm of ideas, principles and beliefs of a certain field of activity and knowledge, as Vărzaru shows (1984: 32), it is also a spiritual and intellectual exercise that does not entail a strict scientific method.

It is in this context that travelling can also be associated with a state, as shown by Cmeciu \& Drugă (2011: 753), namely, "the state of a traveller". This state is related to the sense of personal authenticity that sends to further distinctions between the terms tourist and traveller. In their study, the two researchers prove that the tourist is a "pleasure-seeker" whereas the traveller is a "torment-sufferer" (ibid.), which means that "the tourist finds his fulfilment by accomplishing an external route", whereas "the traveller follows a path of inner fulfilment and becoming" (ibid.). On this background, the authors discuss the (possible) transformation from the condition of a tourist into that of a pilgrim "as a selfdiscovery-seeker" defining the experience of the persons visiting sacred sites. ${ }^{3}$ The interpretation given by Bauman to the concept of "pilgrim" involves a movement forward, toward "a point of arrival" chosen fairly early in life and unfolded on a trajectory that would "not bend, twist or warp, come to a halt or turn backwards". In the sociologist's approach, pilgrims are the predecessors of tourists, and in the case of the new typology - the tourist - the length of stay and the next destination point is hardly ever planned beforehand; the point of the tourist's journey is to be on the move (Bauman 1998: 90). Bauman takes the analysis further, proposing a new syntagm, that of "vagabond", which would be the type of traveller who is asked or pushed from behind to move, and therefore, uprooted "by a force too powerful, and often too mysterious, to resist". Though he insists that these are only metaphors of contemporary life (ibid.: 92), we can also understand the interpretation as a literal one of actual, concrete "journey farers".

The origin of the two main terms employed in our study reinforces these distinctions in point of their historical determination and semantic implications.

\footnotetext{
${ }^{3}$ For a detailed analysis see Cmeciu, Camelia-Mihaela; Drugă, Luminiţa. (2011). Romanian Monasteries: Signs of Tourist Attraction and Self-Discovery. In The European Legacy: Toward New Paradigms, 16:6, 751768.
} 
The term traveller dates from the late fourteenth century with the original meaning of "travail", toil, painful or laborious effort ${ }^{4}$, while some definitions of travel point out the "experiential element of 'transit', 'transport', 'translation', or 'alteration' ", as Bracewell \& Drace-Francis (2008: 3) indicate. The term tourist is of a much later date, in use from the latter half of the eighteenth century, 1772, and refers to "one who makes a journey for pleasure, stopping here and there", originally especially a travel-writer so his itinerary is not internalized or perceived at deeper levels of his existence, whereas a traveller was "an active man at work" (Boorstin 1992: 85). As Boorstin discusses, even since ancient times travellers have been (or were, if we consider travelling as a "lost art", as shown before) incited to action by the willingness to see the unfamiliar, to escape boredom, to discover the exotic, to stimulate the mind, the spirit or the imagination (ibid.: 7879), or to shape up one's education (ibid.: 82).

Travelling involves a cyclical movement and itinerary: people set off only to return after a while to the place they started from, ideally in an improved condition (Nişcov in Kunisch 2000: 27). The return does not necessarily imply the same route - unlike walking, travelling is not a straightforward itinerary but a winding path towards discovery and self-discovery, as Vărzaru (1984) points out. Travelling is a thus a formative and a transformative experience because genuine travelling involves a transformation, a metamorphosis that transforms the human spirit, or an aesthetic, spiritual, cognitive and/or intellectual initiatory experience. The ideas of metamorphosis and improvement are interrelated and, unlike tourism, travelling involves making contact with other cultures in the sense that the traveller "becomes cultivated" and is imbued with the spirit of the place after "having grasped its distinctive essence", which is also referred to as culture (Schulz-Forberg 2005: 44).

Providing the appropriate mood or state of mind, travelling also enables a kind of liberatory escape - escaping home, its boredom and routine, or the conventions of the society. It may also be the case of the contemporary tourist who finds travelling as a means of escape from stress, ennui, or exhaustion. Nevertheless, the way in which the tourist experiences the act of travelling makes him look for copies of what is original, for simulacra or artificial products and indirect experience as an alternative to direct experience, whereas travellers are in search of authenticity of space, feeling and experience, although nowadays tourism often advertises and

\footnotetext{
${ }^{4}$ http://www.oxforddictionaries.com/definition/english/travel?q=travel, accessed October 5, 2014; also explained by Boorstin 1992: 85 .

${ }^{5}$ According to the Online Etymological Dictionary, http://www.etymonline.com/index.php?allowed_in_frame=0\&search=tourist\&searchmode=none, accessed October 6, 2014.
} 
promises authenticity at the core of the touristic adventure, as signalled by Boorstin (1992) or MacCannell (1989: 14).

\section{Travelling across the ages and a brief overview of the history of travel writing}

As shown by Youngs (2006: 2-3), travel writing blends scientific inquiry, subjective perception and ideological positioning, a definition which assists our present study:

"Travel writing is not a literal and objective record of journeys undertaken. It carries preconceptions that, even if challenged, provide a reference point. It is influenced, if not determined, by its authors' gender, class, age, nationality, cultural background and education. It is ideological." (Youngs 2006: 2-3)

Defining a literary form that draws on the conventions of other literary genres, travel writing generally involves both artistic creation and documentary or journalistic aspects, thus constituting a frontier or borderline discursive structure (Andraș 2003, Cazimir 1982). It has thus often been regarded as a "problematic genre" because of its indeterminate nature, mixing "subjective and objective styles, fictional and non-fictional discourses, plot-driven and episodic narratives" (Chirico in Bracewell \& Drace-Francis 2008: 27-60). Taking on various functions, travel writing has revealed its purposes and instantiations as means of reporting the world, revealing the self, performing gender or nationality, or representing the other, as discussed by Thompson (2011).

The origins of travel accounts can be traced back to the classical times, but it was from the sixteenth century onwards that extensive explorations of Asia, parts of Africa, the Near East, the Middle East, or the Far East took place. The era of overseas commercial undertaking and colonization was initiated in 1496-97 by the visit to the Newfoundland of the Italian navigator and explorer John Cabot, commissioned by Henry King VII. After the defeat of the Spanish Armada in 1588, English merchant voyages to the Indian Ocean began.

In the seventeenth and the eighteenth centuries, travelling was particularly associated with enlightenment and the acquisition of knowledge or learning as well as with socialization. By the nineteenth century, Britain's exploratory travels to other continents had also led to forms of conquest and colonization of other peoples. Modern attitudes towards travelling define it mainly as an opportunity to write, to gain knowledge of oneself, to create or travelling simply takes place for its own sake. 
The writings ${ }^{6}$ produced by many of these travels impacted the world of knowledge and culture in general. For example, the exploratory pursuits resulted in scientific investigations that benefited the universe of knowledge. Early records of an Englishman travelling abroad mention Willibald, who travelled to Rome with his family in $718 \mathrm{AD}$. Later, in the sixteenth century, exploratory journeys led to the proliferation of travel accounts, such as Anthony Jenkinson's trip to Russia (1557) or Thomas Dallam's journey to Constantinople (1599). In the latter half of the sixteenth century and the beginning of the seventeenth century, accounts of exploratory journeys had a substantial contribution to the scope of knowledge of that time, including Martin Frobisher's Third Voyage to the NorthWest (1578), Henry May's Voyage to the East and West Indies (1591-4), Raleigh's discovery of Guinea (1595), or Sylvester Jourdan's discovery of the Bermudas (1609).The seventeenth-century accounts of exploration, adventure and discovery by British explorers include William Lithgow's The Totall Discourse of the Rare Adventures and Paineful Peregrinations (1632), William Dampier's A New Voyage around the World (1697) (Dampier was the first person who circumnavigated the world three times), Joseph Pitts's A True and Faithful Account of the Religion and Manners of the Mahometans (1704), Henry Maundrell's A Journey from Aleppo to Jerusalem at Easter AD 1697 (1703).The narrative and the stylistic presentation of these accounts reflected the scientific nature of the endeavours and resulted in realistic, factual presentations of authentic experiences, places and people.

The gradual improvement of transport led to easier travelling in the eighteenth century and travellers were also stimulated by the philosophical tenets of the Enlightenment thinking. Numerous travel accounts by English writers who travelled around the world, to the Ottoman Empire, India, around the Mediterranean, Asia, Africa and various parts of Europe confirm that travelling was a source of inspiration, a way of enriching one's knowledge and the result of intellectual or creative inquisitiveness, e.g. Daniel Defoe's A Tour through the Whole Island of Great Britain (1724-6), Henry Fielding's Journal of a Voyage to Lisbon (1755), Lady Mary Montagu's Letters ... During Travels in Europe, Asia and Africa (1763-67), Laurence Sterne's Sentimental Journey through France and Italy (1768), Samuel Johnson's Journey to the Eastern Islands of Scotland (1775), or James Boswell's Journal of a Tour to the Hebrides (1785).

\footnotetext{
${ }^{6}$ The examples of travel works by English travellers from the sixteenth to the nineteenth centuries given in this section have as a primary source the entry on "travel book" in Cuddon, J. A. (1999). The Penguin Dictionary of Literary Terms and Literary Theory. $4^{\text {th }}$ edition. London, UK: Penguin Books, 937-942. A general survey of travel writing in history can be found in Thompson, Carl. (2011). Travel Writing. Taylor \& Francis e-Library. Ch. 3. Travel Writing Through the Ages: An Overview, 34-61.
} 
In the nineteenth century, travel accounts by English scientists, explorers, missionaries, sailors, Orientalists (Charles Darwin, David Livingstone), or writers aimed primarily at the provision of knowledge: Charles Darwin's Voyage of the Beagle (1839), George Borrow's The Bible in Spain (1843), Eliot Warburton's The Crescent and the Cross (1845), Richard Ford's A Handbook for Travellers in Spain (1845), W.M. Thackeray's Cornhill to Grand Cairo (1846), Sir Richard Burton's Personal Narrative of a Pilgrimage to El Medinah and Meccah (1855) or Unexplored Syria (1872), David Livingstone's Travels to Africa, Lady Duff Gordon's Letters from Egypt (1863-5), C.T. Newton's Travels and Discoveries in the Levant (1869), Sir Henry Stanley's Through the Dark Continent (1878), W.H. Hudson's The Purple Land (1885), Mary Kingsley's Travels in West Africa (1897) etc. Nineteenth-century travellers were well-read before they started their journeys, often taking books or additional materials with them (guides, dictionaries, maps), which marks this century as the first step towards "an encyclopaedic type of gaining knowledge of the world through travelling", as Vărzaru (1984: 10) highlights.

Travelling due to reasons of work and knowledge or for commercial, political or diplomatic purposes (such as soldiers, traders, scientists, educators, or diplomats) continued. However, towards the end of the eighteenth century travelling began to have a meaning in itself (Berindei 1989: 5). Consequently, travel writing gradually shifted from the more scientific, informative, fact-based accounts to the more artistic, literary ones that bear the subjective and expressive imprint of the traveller.

Travel texts by writers have constantly unfolded the multiple possibilities opened up by the travelling experience besides purely scientific or intellectual purposes. Its creative or aesthetic potential is best observed in travel texts such as those written in the late nineteenth century and the early twentieth century, whose features also reflected the British mentality concerning colonial expansion, ideas of domination and commercial expansion, as shown by the writings of Joseph Conrad, Rudyard Kipling, R.L. Stevenson, Jack London, or Somerset Maugham.

Given this background, in historian Roy Bridges's view, travel writing in the nineteenth century reached "a position of influence greater than had ever previously been the case and certainly greater than was to be the case after 1914" mainly because "the developments of the previous 200 years had effectively created one world" (Bridges, R., 2002, "Exploration and travel outside Europe (1720-1914)", in Hulme \&Youngs 2002: 67). It was also the case of significant, though scarce, travel accounts written by Romanian travellers in this period that were to leave an important legacy for the future generations. 


\section{Travel accounts to and from Romania in the nineteenth century}

Historically, few travel accounts were written before $1870^{7}$, even though after the end of the eighteenth century collections of travel accounts became more numerous in Europe, including Romania (Berindei 1989: 6). Although foreign travels to Romania ${ }^{8}$ occurred only in small numbers in comparison with those of the British to foreign lands, some texts emerge as valuable accounts with a predominantly cultural flavour, such as Mary Adelaide Walker's Untrodden Paths in Roumania (1888), Richard Kunisch's Bucharest and Stambul. Sketches from Hungary, Romania and Turkey (1861), or Florence Berger's A Winter in the City of Pleasure; or, Life on the Lower Danube (1877). For instance, Berger speaks about the distinctive identity of the Romanians (the only Latin country at the crossroads of cultures in a largely Slav-inhabited region) and critically depicts Bucharest as "not the East, still less the West", a capital deficient in activities engaging the intellect and abounding in social pleasures:

"Bucharest is Bucharest, and therefore is not the least like any other place in the world. Just as a Roumanian is a Roumanian without a shadow of resemblance to a Turk, a Bosnian, a Galician, a Serb, a Montenegrin, or a Greek. ... Life in Bucharest is facile, and is made up of the customs of many lands. Here, in this ancient capital of Phanariot and Hospodar, is sounded the fin-mot of Western civilisation, and the neophyte gets his first initiatory plunge into Oriental sloth, and effeminate luxuriousness. An idle, gay, monotonous city, with rudelypaved streets, and not the faintest sign of intellectual life stirring on the surface of society." (Berger1877, pp. 35-7 in Youngs 2006: 21)

Though by different means and focusing on dissimilar aspects, such works by foreign travellers to Romania help drawing the history of the Romanians, as $\mathrm{N}$. Iorga (1980) shows, whereas Vărzaru (1984: 7) adds that they can also assist the writing of a history of Romanian civilization. In terms of national identity, founded on a number of variables defined by A.D. Smith (1991: 14), such as a historic territory, common myths, historical memories and values, a common public culture, common legal rights and duties, or a common economy, these travel accounts by foreign travellers set down in writing important aspects defining our

\footnotetext{
${ }^{7}$ A significant body of travel accounts was written by the 1848 Romanian revolutionaries, including Heliade Rădulescu, C. Negruzzi, Grigore Alexandrescu, Cezar Bolliac, M. Kogălniceanu, Alecu Russo, or Vasile Alecsandri (see Cazimir 1982: 8-9).

${ }^{8}$ Also see the following anthologies: Călători străini despre Țările Române edited by Maria Holban (Volumes. I-X, covering the period (1968-2001), N. Iorga. Istoria românilor prin călători - up to the nineteenth century; and Dan A. Lăzărescu. Imaginea României prin călători (1985, vol. I, 1716-1789; vol. II, 17891821), or Simona Vărzaru (ed.). Prin Țările Române. Călători străini din secolul al XIX-lea (1984).
} 
nation's identity which, at the time, was still making its way to a unified modern state.

As far as Romanian travellers abroad are concerned, important travels of Romanian explorers, as described by Hilt (1972) started in the seventeenth century, with Nicolae Milescu Spătarul's travels across Siberia and China (a Marco Polo of the seventeenth century according to Hilt (1972: 7, 11)). Among the first Romanian intellectuals who explored the world with a scientific interest (e.g. geographical) Hilt (1972) mentions Dimitrie Cantemir's expeditions in the eighteenth century to Persia, those undertaken by Ilarie Mitrea and Ion Arseniu (doctors who carried out ethnographic research expeditions in Mexico and Indonesia), Iuliu Popper (an engineer who travelled to India, China, Japan, and North America). In the nineteenth century, D. Ghica Comănești and his son, Nicolae Ghica Comănești travelled to Somalia with the purpose of geographical observation, politician Nicolae Rosetti travelled to the French colonies in Africa, professor of geology Gregoriu Ștefănescu explored the lands of North America and Russia and Emil Racoviță took a naturalist's interest in the Antarctic.

Among the nineteenth-century leading Romanian scholars who travelled to Europe, the names of Dinicu Golescu, Ion Codru-Drăgușanu or N. Iorga are still remembered as prominent figures who enabled Romania to interact more with the wider European space and to establish cultural contact with other European countries. Dinicu Golescu (1777-1830), a Romanian boyar and man of letters wrote Însemnare a călătoriei mele (Recording of my journey) (published in 1826) after he travelled through Europe between 1824-1826. Golescu's work is the first consistent travel text and the first travel journal of a Romanian in Western Europe, reflecting the instructive, critical look of the traveller who is interested in bringing the European civilization closer to the Romanian people. Ion Codru-Drăgușanu's Peregrinul transilvan. 1835-1848, (The Transylvanian Peregrine), the text which is the main focus of the present paper, recounts his travels throughout Europe: Austria (Vienna), Italy (Rome, Milan, Naples, Island of Elba), France (Paris), England (London), Switzerland (Thun, Geneva), and Germany (Frankfurt). His visits to London in 1840 and 1843 constitute some of the earliest and most valuable eye-witness accounts depicting the English culture set down in writing by Romanian travellers abroad. An important representative of the genre is $\mathrm{N}$. Iorga (1871-1940), whose accounts of his numerous travels abroad between 1890-1939, especially for studies, are included in Călătorii peste hotare (Journeys Abroad) (1980). Iorga travelled to Italy, Serbia, Bulgaria, Turkey, Greece, Great Britain, Spain, Portugal, Sweden, Belgium, etc. for intellectual purposes, with self-improvement as a main target, but also in order to enrich the Romanians' knowledge about their own country's history. Thus, he endeavoured 
to retrieve or revive less known parts of Romania's history from archives and library collections, gathering information which contributed extensively to expanding the amount of knowledge about Romania's history, as Iorga himself confessed in $O$ viață de om așa cum a fost (1972, p. 272, in Iorga 1980: xi). His travels assisted him in acquiring knowledge about other countries he came into contact with, but he also used this opportunity to reflect on our own historical and cultural heritage and hold up a mirror that would benefit our knowledge of our own country. Travelling to England in 1892, he admires the highly disciplined energy and good organisation of the English, the English landscapes, the famous English garden, the country's ancient history, its political and military power, the arts, or education with its renowned universities. Although he reveres the harmonious blending of old and new, past and present, he subtly criticizes social differences and the dire poverty of many people. Finally, another man of letters whose travel accounts enriched both the extent of the genre and the Romanians' knowledge of England in the former half of the twentieth century was Marcu Beza (1882-1949), who produced two noteworthy studies: Din alte țări: studii și impresii (From Other Countries: Studies and Impressions) (1933) and Din Anglia. Insemnările unui literat (From England. A Scholar's Notes) (1938).

In Geografile simbolice (Symbolic Geographies) (2008) Carmen Andraș lists a number of at least twenty books or articles by English or American writers depicting Romania, thus showing the fascination with eastern Europe in the twentieth century which continued well into the twenty-first century. Novels or travel accounts with both fictional and historical import include those written by Donald Hall, Romanian Furrow (1933, an account of travels in rural Romania in 1932), Olivia Manning, The Balkan Trilogy (1960, a description of Romania during WWII), Tom Simon, The Gypsy in Me: From Germany to Romania in Search of Youth, Truth, and Dad (1997), William Blacker, Along the Enchanted Way: A Story of Love and Life in Romania (2010), Georgina Harding, Painter of Silence (2012, recalling the post-war Romania of the 1950s), Teresa Dunlop, To Romania with Love (2012) and many others.

\section{Travel writing and writing on travel. Ion Codru-Drăgușanu's travel accounts to England in the nineteenth century}

\subsection{England in the nineteenth century. The socio-cultural context}

Taking place during the reign of Queen Victoria (1837-1901), a time of significant change in many aspects of British life, Codru-Drăgușanu's travels to England in 1840 and 1843 were backgrounded on numerous features of social, 
cultural, economic or political life discussed, among others, by Paterson (2008) and Mitchell (2009).

A century earlier, in the eighteenth century, the emergence of the capitalist society invigorated the economic activity and the rise of the bourgeoisie composed of merchants, traders, businessmen, entrepreneurs, factory owners became an important factor in increasing Britain's wealth which, in turn, led to the organization of numerous explorations or expeditions around the world. At a national level, the common people's voice started to be heard more noticeably after 1838 when the People's Charter pleaded for voting rights for the working class, and the first trade unions were organized in 1851. Thus, the privilege of high social status gradually diminished and the lower classes of the society or the working men started to ask for rights that are now considered as perfectly normal and democratic.

Social and political reform characterized the entire period. Additionally, Britain's commercial undertakings abroad combined with a keen interest in knowing and civilizing the non-European world contributed to Britain's position of supremacy as an overseas trade empire. The period 1830-1880 was one of Victorian global expansion characterized by significant "confidence about Britain and its place in the world", whereas the period 1880-1914 was one in which harsh international rivalry and "territorial annexations were accompanied by considerable anxiety" (Bridges, in Hulme \& Youngs 2002, p. 54). Britain's increasing role and presence in numerous parts of the world was remarkable as Sir Charles Dilke suggested in the preface to his Greater Britain in 1880: "In 1866 and 1867, I followed England round the world: everywhere I was in English-speaking, or in English-governed lands" (Youngs 2006: 6).

An economic, political and cultural centre and a cosmopolitan space, London had become Europe's largest city by the middle of the eighteenth century and attracted many travellers from all over the world. An efficient urban system due to efficient transportation means and a functional communication infrastructure led to the building of the first public passenger railway in the world (the Stockton and Darlington Railway) in 1825 (Oakland 2011: xx), the peak of the industrial revolution thus changing the face of the English society in many ways.

\subsection{The author's and the text's context}

Codru-Drăgușanu's first letters were published anonymously in March 1863 in Concordia newspaper from Pesta and the serialized publication continued until 
January 1864 . They were first published in a volume in 1865 , containing 32 letters written after the travelling period ended, which signals that some kind of adjustment may have taken place.

The original text published in Concordia newspaper poses some difficulties for the contemporary readers because it was written according to the etymological orthography established by Timotei Cipariu, a system that was common to periodicals and books published in Transylvania in those times. In 1910, a new edition appeared, edited by Constantin Onciu and prefaced by N. Iorga, which was easier to read, making the text "one of the most pleasant readings", as Iorga shows in Cum să cetim și să înțelegem arta (How to Read and Understand Art) (1930: 20), after removing its Latinisms and divesting it of Cipariu's orthography.

Ion Codru-Drăgușanu's biographical itinerary and his reasons for travelling assist the contextualized interpretation of his travel letters. Born in a noble family in Drăguş, Braşov in 1818, Ioane Germaniu Codrea expanded his knowledge in the library of Mrs Blum Babejac ${ }^{9}$ and then had boyar Constantin Câmpineanu as a patron and mentor, studying in his library and accompanying him during official visits in the country and abroad. Ion Codru-Drăgușanu was an educated traveller, similar to other literate travellers such as Nicolae Milescu Spătarul, Constantin Cantacuzino, or Dinicu Golescu. ${ }^{10}$

Some of his reasons for travelling included the eagerness to leave home, to move forward, to fill a void or some absence, to look for something that he could not find at home, thus endorsing Iorga's (1980) and Kunisch's (2000: 34) assumptions concerning the most common reasons for travelling. Codru-Drăgușanu set out on a journey motivated by his thirst for knowledge from early childhood or for intensive study and meditation (as shown in the first letter) as well as by his desire to improve his knowledge of foreign languages (German, French, Greek). However, his patriotic feelings made him desire to know Wallachia first. Later, he worked as a librarian in Paris but again longed for travelling around the world in order to gain life experience, so wanderlust awaked in him (Letter XXIV). During his travels he was an interpreter, served as a prince's adjutant, or worked as a guide, secretary and courier.

\footnotetext{
${ }^{9}$ Albu, Corneliu. Preface to Codru-Drăgușanu, Ion. (1980). Peregrinul transilvan. 1835-1848. București, Romania: Editura Sport-Turism, 9.

${ }^{10}$ According to Borda (1983), other important early Romanian travelers had no erudite training, such as Nicolae Olahus, Petru Cercel, Samuilă Damian, George Pomuț, Badea Cârțan, Mihai Tican Rumano or Nicolae Ghimpu.
} 


\subsection{Stylistic features}

The textual features of the letters reveal both literary and documentary character. The text's literariness derives from the artful combination of elements of autobiography, subjective commentary, linguistic inventiveness and stylistic richness (including anecdotes and other means of creating humour, figures of style), or the use of the epistolary technique itself. The epistolary form assisted both the realistic presentation (autobiographical accounts of former travelling experiences across Europe suggesting authenticity, plausibility, facts of real life in a confessional style) and the subjective representation of the travels. Given that there is no record of a real exchange of letters between Codru-Drăgușanu and the addressee of his letters, perhaps the epistolary form offered him the necessary medium for making the shift from public to personal, from objective to subjective representation, from matter-of-fact reporting to highly personalized, confessional, emotional accounts written in an embellished style. Letters transmit factual information, but they also mirror the feelings and personal experiences of the writer so, in Codru-Drăgușanu's text, notes of disclosure and confession, autobiographical reverberations, introspective tonalities blend with social, cultural or political information describing the English life. Hence, the text confirms Anne Bower's (1997: 10) statement that the epistolary mode has always been related to "the aesthetic, critical and philosophical issues" of a certain age.

In fact, although the text is also instructive and informative and the author is wellinformed on itineraries, geographical data, historical references, monetary aspects or other similar information, he openly rejects to present such aspects in his writings ("I do not want my writing to resemble geographical or statistical accounts." (p. 13) and so the documentary purpose of the text or that of realistic presentation (the claim of truth, authenticity, plausibility, realism) is only secondary to the primary aim of shedding light on his personal experience and consciousness, of recording his subjective impressions and filtering them through the world of his own perception.

The descriptive details (numbers, details about box fighting, experiments seen at the Royal Polytechnic Institute, the way in which the centrifugal railway works, descriptions of dishes, the eating habits of the British, famous locations, the description of the Lord Mayor's Ceremony, of a lord's mansion in the countryside or the minute depiction of the natural scape surrounding the castle) have the purpose of offering realistic information to the readers so that they may take it as genuine and trustworthy. On the other hand, he intersperses his personal impressions and reactions and openly expresses his feelings. For example, in Letter XVIII he comments "I found it extraordinary that..." (p. 124), "it seemed 
bizarre" (p. 125), or he openly expresses his dislike for the English language which "scratches" his ears because of so many "monosyllabic words" (p. 126). The reporting combines emotive language (intended to express or arouse emotional reactions related to the subject) and the referential use of language (that aims only to denote, in a manner similar to the language of the scientist).

Therefore, his accounts combine historical data, geographical observation, factual details about places, cultural events, customs, ethnographic observation, natural descriptions, social data, information about infrastructure etc. thus lending authenticity to the presentation. Conversely, the authenticity of feeling and the intensity of experience add to the subjective and individualized interpretation of the travelled world. To give another example, after stating that there are only two great nations in Europe, he makes a simplified comparison between the French and the English, arguing that the former are inconstant, revolutionary, and great lovers of luxury, whereas the latter are constant, enterprising, even rather selfish (p. 119). The motto he chooses (from Sallustius Crispus) praises the two nations' strengths, pointing out that it is their struggle to achieve or obtain freedom that produces both wealth and glory (p. 119). In so doing, he employs clichés and national stereotypes that signal the tendency to resort to simplistic notions at the expense of first-hand knowledge.

On the other hand, the experiencing of novelty stimulates the drawing of comparisons, so his analytical look becomes a tool for the carrying out of sociocultural analysis. Thus, the acquiring of knowledge of other cultures helps him improve his familiarity with his own culture, while at the same time he reinforces his own identity and the Romanian cultural heritage in general. A messenger and a promoter of genuine Romanian values abroad, he acts as a bearer of the ancestral Romanian values and takes great pride in openly placing some aspect of national identity on a superior level. This is what happens at the Zoological Garden where he shows no amazement when seeing the buffalos, regarded as wild beasts in England, and even puzzles the guide when informing him that he was raised with buffalo cow's milk (p. 125). Therefore, one of the definitions given by David Chirico (in Bracewell \& Drace-Francis 2008: 38) to travel narratives seems to suit Codru-Drăgușanu's text as a "non-fictional first person narrative describing travel to or residence in a place and explicitly or implicitly comparing it with a place of departure", which obviously leads to the construction of a "discourse of difference" (ibid.), as will see below. In so doing, the highlighting of English national specificity as compared to Romanian national specificity becomes the primary goal. 


\subsection{Letters from London. The representation of London life}

Three of his letters (XVII and XVIII, September 1840 and XXXIII, November 1843) depict various features of the English life ranging from commerce, architecture, social or political aspects to language and cultural aspects that were little known to many of his contemporaries.

National specificity is framed by means of descriptions of local places and social practices, as well as by means of cultural contrast, generalization and stereotypical representation. However, as we shall see, national specificity is doubly targeted, with descriptive and critical observation on both the English identity and the Romanian one, as a part of his often applied contrastive method.

The very beginning of Letter XVII contains a generalizing statement that attributes power in Europe to two states only, England and France, and further claims that, in fact, the two nations ruled the world (p. 119). Moreover, according to some unnamed "writers" (ibid.), Greek and Roman features are reminiscent in both nations' characters. Unlike the French, the English are supposed to be constant, following the steps of the Romans, whereas their speculative spirit or their selfish interests draw them closer to the Greeks. Letter XVIII also opens with a motto from a sarcastic German ${ }^{11}$ and stereotypically defines the English spirit in view of some generalized features concerning their lifestyle and leisure activities (tea drinking, making idle conversation), the men's supposed intellectual sharpness and witty tongues or the ladies' more emotional nature. In what follows, by means of his direct contact with the English culture, he intends to test this "theory" (p. 119), meaning his theoretical knowledge, with practical findings although, at time, he will still make use of simplified or standardized conceptions ingrained in public consciousness.

The Romanian traveller was first of all amazed by the size of the capital, a crowded "monstrous metropolis" (p. 219) which contained a whole world in miniature due to its two million residents and its multifaceted life. The growth of the city was largely explained by or resulting from the industrial development, the urbanization process and the land enclosures, making the London area one that had continuously expanded and engulfed personal properties.

Traditionally renowned as a global trade power, London is, in the traveller's view, the "home of universal commerce" (p. 218). This belief is underpinned by the fact that the English people are a nation of traders, with business in their blood, which

\footnotetext{
11 “They sat drinking tea, eating/And talked a lot about love/The men were witty/And the ladies with their delicate feelings" (p. 124).
} 
makes them faithful to it until the end. Hence their concern with ceremonies celebrating trade, including one he is witness to, the Lord Mayor's ceremony on 9 November. Minutely describing the entire procession, he characterizes it as one befitting a king (p. 218). Financial potency was an essential criterion for the post given that eligible candidates were wealthy merchants, traders or craftsmen, all of them millionaires who owned shops in the City given that even nowadays the Lord Mayor of London represents and promotes the business interests and the people of the City of London.

The City, "the core of London" was the home of business, a container of small shops owned by merchants and so, an immense generator of wealth. The powerful social class of urban enterprisers (the cits or citizens) obtained their incomes from trade rather than land, and their dynamic engagement in trade or commerce confirmed the mercantilist idea that "work makes worth" (McGirr 2007: 64-7). Another significant socio-economic group that formed the powerful middle class was that of the rich factory owners, whose production capacity and, therefore, financial power in the peak of the industrial era were immense since they could "load ten, maybe twenty ships in any port at your choice" (p. 126). The political influence of merchants was also noteworthy. In line with the regulations of constitutional monarchy, the official powers of the Queen were limited, while the wealthy merchants acted as a counterbalancing force for the royal power and impeded any possible political abuse. Even more, they influenced political decisions and changed the course of politics according to their interests (p. 126).

Still related to the world of politics, the description of the two-party political system, with the Tories and Whigs taking turns to rule, is meant to offer valuable insight into a different political system that, on the whole, makes England the mother of political liberty (pp. 120-121). The metaphorical and pejorative phrases used by each party to describe the other are related to the temporal setting of his journey and are also historically rooted: the Tory party was an aristocratic group and meant "tough crust" (which can also send to the informal noun "upper crust" (1830), which denotes the highest social class in a society) as opposed to the Whigs, a term which signifies "juice/a liquid" or mashed fruits. Dating from the beginning of the nineteenth century, "whig" meant in Scottish "a thin and sour liquid", a watery fluid, used pejoratively with reference to the poor Presbyterians in Scotland who had to drink this kind of liquid (Whiter 1822: 871), also a shortened form for Whiggamor (1649), meaning cattle driver ${ }^{12}$, a supporter of the Presbyterian cause in western Scotland who marched to Edinburgh in 1648 to

\footnotetext{
${ }^{12}$ http://encyclopedia2.thefreedictionary.com/Whiggamore, accessed October 15, 2014.
} 
oppose King Charles $I^{13}$ and later opposed the succession of the Catholic Duke of York (later James II). ${ }^{14}$ Traditionally, as Codru-Drăgușanu intuitively perceives by interpreting the two metaphorical expressions, the Whigs came to be associated with socio-political reform, support for commercial enterprise, the limitation of royal power and more liberal thinking and democratic ideas, whereas the Tories represented the interests of the country gentry, supported royal prerogative and hereditary rights, their tough 'crust' alluding to their impermeability in terms of reform, novelty and change in the society. Unlike them, the Whigs were more flexible and adaptable, advocating liberal principles.

Equally interested in social aspects, Codru-Drăgușanu also describes the typical social organization, which reproduces the traditional British social structure and comprises the aristocracy at the top of this arrangement, then the middle class of tradesmen, merchants and industrialists and, finally, the lower classes, including workers or the servants in the aristocrats' homes. Particularly surprised by the social inequality and imbalance, he observes that over two hundred servants attended not more than seven people. The large number of servants and the existence of various categories of attendants were also impressive for the Romanian traveller. Therefore, the first group included butlers, administrators, secretaries, treasurers, governesses, chaplains, and doctors. The second comprised chamber maids, chefs, vets, or servants who waited at tables. In the third class, the chef's assistants, footmen, or stable servants could be found. Attended by such a large number of servants, the aristocrats were not producing their wealth, as the merchants did. Unlike them, the aristocrats spent their time hunting excessively, which led to the decimation of the fox population in many areas. Fox hunting became a typical aristocratic pastime, a "noble amusement" (p. 221) and even their main activity, the ritual and the hunting outfit being minutely described for informative purposes as well as for educational ones which could be useful for the Romanian nobles.

His curiosity in terms of religion also gives occasion for critical commentary related to the Catholic, Anglican and Orthodox religions (p. 122). Appraising both negative and positive aspects concerning the three religions, the Orthodox believers stand out as possessing a more profound religious devotion as compared to the Anglicans but, unlike them, together with the Catholics, they are less orderly in terms of respecting and upholding the "dignity of the cult" (p. 122), having transformed the church into a "theatre" (ibid.). The Anglicans' careful observance of the rules of the cult as, for instance, the fact that nobody works on

\footnotetext{
${ }^{13}$ According to the Online Etymological Dictionary, index.php?allowed_in_frame $=0 \&$ search $=$ whig\&searchmode $=$ none, accessed October 9, 2014.

${ }^{14} \mathrm{http}: / /$ encyclopedia2.thefreedictionary.com/Whiggamore, accessed October 15, 2014.
} 
Sundays and all the citizens spend their Sunday mornings paying religious reverence is positively regarded by the traveller who believes there should be a balance between religious faith and the strict observance of its manifestation in the form of rituals.

In point of culture, as a traveller who is interested in gaining knowledge of the cultural life of the host nation, he visits the British museum where the collection of statues from Egypt, Greece, Italy and India, and the rare objects bought by wealthy lords and donated to the "patriotic museum" (p. 124) fascinated his inquisitive nature that was little familiarized with the heritage of world culture.

His commentaries also focus, though briefly, with a hasty visitor's remarks, on the wide variety and large number of public spaces available for leisure activities, relaxation or assembly. The famous London parks, Regents, Green, Hyde and Saint James Parks, impress the traveller through their size, imposing trees and crystal-clear lakes, while the squares compensate for the parks' short supply of flower beds (p. 122). His comments on his brief visit to the Zoological Garden, described as the most complex in Europe, results only in little information regarding its diversity, with a quick numerical note on the existence of "four elephants and six beautiful giraffes" (p. 124).

In point of civilization or that degree of social, cultural and technological evolution, Codru-Drăgușanu stereotypically reproduces the contrast between the 'civilized westerner' and the 'eastern barbarian'. By placing the British nation on top of civilization ("Great Britain is the most civilized state in the world"), a conclusion drawn due to the admirable public order in the capital, where no soldiers could be seen on the streets, he equates public order with an advanced society. However, public order was maintained by the constables, compared to "a species of police officers" (p. 126), signalling that less public order was to be expected in Romania at that time. Another aspect of civilization observed is related to infrastructure, particularly the streets, whose characteristics (wide, straight, clean, covered in wood or asphalted) made them efficient means of communication and transportation. Although from a different perspective, boxing games contradicted this state of civilization in "Box Halls" where "English gladiators" used their fists in combat with utter cruelty. Resorting to cultural contrast again, he comments that such a "barbarian fight" (p. 125) seems contrary to the Romanian love for peaceful encounters.

Architecturally, the houses were rather simple and not very solid, unlike those in Paris where the style of building is described as exquisite or monumental (p. 121). The luxurious taste of carpeting the stairs, both indoors and outdoors, is 
nevertheless determined by the rainy weather. His remarks on the face of the town presented above suggest that Codru-Drăgușanu visited the wealthy sectors of the nineteenth-century capital, where the rich lived in elegant, well-built houses surrounded by gardens, whereas the poor inhabited overcrowded, back-to-back houses in noisy and filthy neighbourhoods. However, the general impression was that of opulence counterbalanced by regularity (p. 220).

Having access to the higher ranks of the society, the Romanian traveller visits a lord's castle, Sherburn House, on a country estate. The houses of the aristocracy from the rural areas of England are presented as sumptuous, elegantly furnished, multi-coloured, yet "simple and solid", comfortable, orderly and, most of all, luxurious (p. 220), as any lord's castle would be. The depiction of a nobleman's house also serves the author's presentation of the typical arrangement of space according to social class, including the family members and the various types of servants.

His architectural sketch of English churches and cathedrals provides little information as that perceived by a tourist's gaze which is not adequately acquainted with or does not take particular interest in the technical aspects. Saint Paul's Cathedral, an architectural monument compared to Saint Paul's church from the Vatican, is only briefly depicted as much smaller and scarcely decorated inside.

The traveller's steps are also guided to some of the most popular places of the Victorian period, especially those connected to the world of science and industrial progress which was opening up to the wider public. As if preparing the Great Exhibition of 1851, the Royal Polytechnic Institute hosted numerous physical, chemical and mechanic experiences which were made in front of an audience, producing lightning and thunder and other experiments which were intensely popularized. Similarly, the "centrifugal railway" was a mechanic wonder described as such, and the traveller feels quite bewildered that people are turned upside down if they travel by it. The tunnel under the Thames is another great wonder of the world that he eulogizes, even arguing that it outshines the most amazing ones of the antiquity. Probably a naive comment or an unsuitable comparison, the statement underlines its focal importance for the British and the result of a communicational necessity between the two river banks. His lack of knowledge probably makes the description rather simple and concise: it was "a gangway with two arcades" (p. 125) although the scientific merits of the invention were highly praised. The steam locomotive, the electrical telegraph or all sorts of "physical marvels" (p. 222) were also quite familiar inventions for the English, given that they possessed the financial resources for their encouragement. 
Due to the numerous scientific inventions of the period such as the development of steam and internal combustion engines, or of electricity and building techniques, Britain came to be known as the "workshop of the world". It is a fact that many of the familiar household objects that we use today had their origins in the Victorian age. Other developments, such as road improvements (tarmacadamed surfaces), the railway (enabling fast transport and greater mobility for the people; an example is The Great Western Railway, founded in 1833, which connected London with Wales and the south-west and west of England), the electric telegraph (1837, facilitating long-distance communication), as well as research on pneumatic locomotives made England a distinguished name in the world of global science.

When speaking of the English language, an essential marker of English identity, Codru-Drăgușanu negatively criticizes this element of national pride and by rebutting it he ends up extolling the beauty of our Romanian language. In his view, the "monosyllabic" character and the conciseness of the English language make it indeed suitable for nautical commands and the author even adds a comical comment in order to underline the pride of the English with reference both to their language and their temper. Thus, it appears that the English themselves are surprised how other nations can actually evolve without benefiting from linguistic conciseness, a feature which is specific to them only (p. 126). However, this very quality turns into a major flaw and the Romanian traveller praises the melodious and harmonious nature of the Romanian language, especially given that singing "requires sonorous, clear vowels, not swallowed and sneezed ones, as it happens in their language" (p. 126). It is then the interdependence between the melodiousness of the Romanian language and the harmonious Romanian spirit that led to the creation of its unique folk music. If the character of the Romanian language makes it very suitable for singing, also a characteristic feature of the Romanian peasant, the unappealing sound and the unmelodious curtness of the English language can even diminish the pleasure of listening to an opera performance, as it happens at Covent Garden theatre. In the end, it may be that both his allegiance to his national identity and his insufficient knowledge of the English language equally contribute to his critical attitude.

His remarks on some typical English customs also make room for cultural contrast. Tea drinking on all occasions is quite unusual for the Romanian traveller who notices that people are offered hot tea even when they want to cool down, a habit which was contrary to the Romanian tradition of drinking "lemonade, orange juice or cold sorbet" (p. 125). On the other hand, he admits the superiority of the English in using the homeopathic principle at the basis of this custom, which was still unknown to the Romanians. 
The traveller's sketchy depiction of the typical English temperament combines such features as trustworthiness, reliability, rigor, discipline, precision and correctness. A common personification of Britain, John Bull, also gives an indirect indication of the English personality. As a character that became popular during the nineteenth century, with its origins in John Arbuthnot's pamphlets The History of John Bull (1712), John Bull was regarded as the representative of the English nation. Nineteenth-century cartoons from the Punch portrayed him as a jovial, honest, stout middle class man, so he quickly came to be associated with the typical Englishman and even England. Earlier in the text Codru-Drăgușanu mentioned another stereotypical phrase, "perfidious Albion" (p. 120), used by the French in relation to the alleged duplicity of the British in their relations with other nations. His repeated use of clichés about national character does reduce the quality of the information presented in terms of its authenticity but it also adds humour to the portrayal of people, places and situations.

With regard to the clothes and way of dressing of the English, Codru-Drăgușanu expresses his admiration of their simple and elegant nature, which generated the use of the adjective "a l'anglaise" to refer to anything that is defined by means of these features (p. 126). Some details caught his attention, for instance, men's elegance, which often rested on the wearing of a black suit and a white tie. As we have seen before, the patriotic feelings of the traveller often make him filter the local information through the sieve of his own culture and thus imbue the host culture with Romanian flavour. For example, he describes the trousers worn by lords at court as "itari", thus pointing out the similarity with the tight homespun trousers worn by the Romanian peasants. Another feature also compares them with the Romanian peasants, namely, thrift. He observes that they do not change their shoes very often but prefer to attach heel plates to their shoes, just as our peasants do.

Though partial and certainly incomplete, his contact with a series of local customs and practices allows him to introduce his observations and his personal commentary related to the typical food and drinks of the English. Starting from the observation that the food was simple but varied in nature, he goes on to describe a typical meal as quite simple and meagre, consisting of steak, plumpudding, (unpeeled) boiled potatoes, bread and butter. Codru-Drăgușanu's traditional nature, his fondness for the typical Romanian food or perhaps his personal tastes make him regard certain gastronomic customs as bizarre and this determines him not to eat steak. Even though meat was tender and game was fattened and kept in parks, it was often undercooked, retaining its juice and redness. The next dish, plum-pudding, the traditional English delicacy, 
(misspelled as "ploom-pudding"15 , p. 127), made of fine flour mixed with plums, is compared to the Romanian polenta, even though the two have little in common. Further on, he compares the English cuisine with the Romanian one again and observes that the former does not contain many dishes which are very appreciated in our country, such as "soups, gravy, salads and thousands of delicacies", which are "despised" (ibid.) here. However, he admits that the food variety is like nowhere else in Europe and this seems to suit the voracious appetite of the English, defined as "the most gluttonous people on earth" (ibid.). Continuing on the same pattern of generalization, he ironizes their appetite by humorously adding that the English eat beefsteak around ten in the morning and drink beer, eat copiously around two o'clock, drink their five o'clock tea and eat again a plentiful dinner. Commenting that "the national drink is beer" (ibid.), he further presents the two types of beer that can be found, namely, porter and ale, the most popular one being ale because the former was a dark-brown, heavy, rather strong type of beer. Besides beer, good wine was also preferred and was generally imported, especially from Spain and Portugal.

Making comments on the standard of living, Codru-Drăgușanu observes that life was expensive, that is why they often lived abroad spending half of what they normally spent at home. National wealth had its downsides, the unequal distribution of riches being a common censure of the class-ridden English society.

Himself a tourist, Codru-Drăgușanu draws a comparison between the English and the Romanian tourists and their travel journals, the differences being ultimately connected to personality features as well as social, cultural or political realities specific to the two nations. Thus, the British loved travelling "in herds" and afforded to travel widely, almost transforming travelling in some kind of profession. The English tourists wrote meticulous, wordy, detailed accounts of the places they visited because they wanted the information they offered to serve as travelling "norms and directives" or guides for their country fellows (p. 214). On the other hand, they also wanted to fill a gap because they travelled extensively but without any aesthetic, intellectual or spiritual reasons, guided mainly by trivial needs, in order to escape routine or melancholy and to gratify their senses: "eating well, drinking well, sleeping well, living comfortably or escaping the spleen" (p. 215). Unlike them, the Romanian travellers did not write such thorough accounts because they travelled much less, they were less difficult or finicky than the English ones and their adaptable nature made them overlook many abnormalities

\footnotetext{
${ }^{15}$ More than that, his poor knowledge of English is paralleled by his use of incorrect information, probably as a result of insufficient documentation or lack of first-hand experience with the reported information. This is because he presents plums as a major ingredient of the dish, misled by its name, not knowing that the Victorians used the term "plums" instead of raisins and so there are actually no plums in it.
} 
or deviations (be they social, political or moral) they found even in the "so-called cultivated or civilized countries" (ibid.). The Romanians often travelled for business or other necessary affairs, or in order to expand their knowledge, just as Codru-Drăgușanu did. However, exceptions included the travels of wealthy people, whose actions revealed the destructive side of travelling when the reasons mentioned above do not apply. Many Romanian boyars travelled only to ruin themselves and were not prepared to rise to the level of Western civilization in point of taste; an example was Dudescu Nebunul (Dudescu the Insane) who acted foolishly in order to show off his wealth (p. 215).

As a traveller to England, Codru-Drăgușanu could not miss the occasion to speak about the famous bad or rainy weather, a common topic of conversation and a defining, though stereotypical, feature of English life. He informs that only September is a pleasant month, which makes it suitable for travelling. In fact, the weather determines the people's regular activities, so the rich people spend the summers in the capital and the winters at their countryside estates. Moreover, the fog and smog resulting from the industrial activity had negative effects on the lives of the nineteenth-century urban people, often driving the residents out of the capital. A related theme refers to the dichotomy city-countryside. In contrast with the mist and darkness of the capital, the beauty of the countryside is expressed in terms of light, tranquillity and unspoiled character. In London, the thick fog provided little visibility in the city, which created the impression of a "perpetual night" (p. 219), whereas in the countryside even when it was foggy the day light was clear.

\section{Ion Codru-Drăgușanu, between a tourist and a traveller}

Although written by teachers, intellectuals, journalists, lawyers, noblemen with little or no literary training, many travel accounts of the nineteenth century had a documentary and a literary value. As in the case of all these, in the case of CodruDrăguşanu as well, his travels do not revolve around a special quest that may benefit his own personal becoming to a great extent and thus influence the process of personal identity formation in a radically transformative manner, but his accounts certainly contribute to the exchange of information and the acquiring of knowledge regarding national identity by acquainting the Romanian people with distinguishing attributes defining the English culture of those times as well as by shedding light on certain aspects specific to the Romanian national identity by way of comparison. 
For Codru-Drăgușanu, the written recording of his travelling experiences becomes the medium for setting down his travel impressions, observations and the information acquired, but also a means of expressing national feelings or the feeling of national belonging, thus reinforcing his allegiance to the Romanian identity in its broad sense. Observing the gap between Romanian and Western European civilization, he tries to reduce this gap by travelling, gaining knowledge of those cultures and imparting it to his contemporaries. At the same time, this process is paralleled by a constant effort of mirroring the many accomplishments of the Romanians in certain aspects, so he ingeniously seizes the opportunity of placing his own country on a superior level in many of those areas.

Consequently, a central feature of his writing is that, as a traveller, CodruDrăguşanu is dominated by patriotic feelings, constantly longs for his native country and celebrates its riches. To this end, he is assisted by cultural contrast in order to underline our country's superiority in point of natural resources, landscape, the beauty of the language, the taste and quality of our food, although he is aware that technically and scientifically it was lagging behind, or that the clash between poverty and richness was a serious problem. The comparison often reinforces the beauty of his home country as compared to the foreign ones. It is in this context that he observes the similarity between the Italian language and the Romanian one, or that between the Lazzaroni (the homeless idlers of Naples) and the trough makers from Brașov (Letter XXVI), or he draws a comparison between Switzerland and Transylvania (Letter XXX), or between the administrative institutions in France and Walachia (Letter XXXIV), etc. Always bearing Romania in mind and aware of its touristic potential despite its lagging behind in technological progress, Codru-Drăgușanu felt certain that as soon as the railway became functional in Romania our lands would be invaded by foreigners who would be fascinated by its natural beauty. That is why, during his stay abroad, whenever he met nabobs, Russian princes, French nobles or English lords he persistently promoted Romania's nature, traditions, or its people in general.

His epistolary travel accounts may indeed constitute a sketchy representation of London places and people and cannot claim to offer a complete picture of life in London in those times or of English identity in particular. His knowledge is partial, consisting of what he could observe during his short stay, from other sources, by experiencing only slices of reality or having contact with some sections of the population, generally the rich one. Additionally, the presentation is brief and, with a tourist's eye, he gives only the essential features of the facts, places and people. The choice of the epistolary form as well as the fact that the essays were intended for publication in a newspaper also justify the general briefness of the accounts and its instructive, informative style. 
His desire to broaden his knowledge, as he himself stated among his reasons for travelling, his aesthetic and intellectual experiencing of novelty, his participative involvement together with his constant critical effort of placing his native country in a positive, even superior, light may secure an important place for Ion CodruDrăguşanu among the most important Romanian travellers of the nineteenth century. All these features take him beyond the role of a spectator or observer and his humorous, witty or mildly critical comments or opinions regarding the characteristics of the places visited create the image of a traveller that seeks to combine the benefits of a pleasurable and entertaining personal experience with those that impact on his knowledge and the knowledge of others. The contact with these cultures is indeed informative but also formative to some extent from an aesthetic, cognitive or experiential viewpoint.

On the other hand, he also displayed qualities more characteristic to a tourist for several reasons. Firstly, unlike explorers for instance, he was not motivated by scientific interests or the methodical or laborious acquisition of new knowledge. There is no intentional study, instruction or careful investigation with the tools of a scientist, nor is there any obvious effort or toil in his undertaking.

Secondly, his travels often generate pleasure and, very much like a tourist, he wants to admire, to gaze, and even asks an acquaintance of his to take him to see the interesting sights or the "rare curiosities" of the city (p. 124). In fact, he explicitly expresses his intention to gain access to some "touristic goods" (ibid.) of the capital and this often leads to sketchy, almost hasty, descriptions of the places visited by a tourist who is constantly on the run. Therefore, the visiting of the sights of London as major tourist attractions of that period is one of his main targets. Originating in his early years, personal curiosity comes first and only after that follows the desire of improving his knowledge. Taking these aspects into consideration, "to see" may be regarded as the main paradigm that defines his travelling experience while endeavouring to balance descriptive detail and personal comment, impression or opinion.

Thirdly, he occasionally tests his prior theoretical knowledge of the visited cultures (information from books) by means of direct contact, but he also resorts to generalizations without testing the information ("they say that..." (p. 126), stereotypes, clichés about English character). By doing so, he fails to reach the deeper stratum of genuine features of English character which is often the result of thoroughgoing observation and experience. For instance, presenting the most typical features that attract tourists to certain European countries, he observes that Germany is attractive to foreigners due to its focus on science and education (its famous universities), the English people are famous for their order and punctuality, 
whereas France is appealing due to its civilization and the arts. Some of the clichés on national character mentioned by Codru-Drăgușanu remind us of those forming the list of "quintessences" of English national identity (pp. 9-13), to use Julian Barnes's term from his novel England, England, such as the royal family, the Houses of Parliament (in Codru-Drăgușanu's letters the composition of the legislative body is presented because the Parliament was not assembled at that date), the class system, the cup of tea, the English breakfast, beer (warm beer) or perfidy (untrustworthiness). Though they claim to comprise the most concentrated essence of national identity, they are utterly simplistic and conventionalized so they cannot function as genuine representations.

Fourthly, although he wants to get to know new people, lands, or customs, his journey does not ingenerate a process of "becoming" (Cmeciu \& Drugă 2011: 753) or a fundamental alteration of his spirit or intellect which is specific to a traveller's experience, as many of the above-cited works highlight. In many ways an onlooker's experience, his travels constitute indeed an initiatory cultural experience without the force of a deeply transformative effect on a personal level.

\section{Conclusions}

All in all, Codru-Drăgușanu's accounts can be seen as a privileged traveller's experience that was intended to serve as useful first-hand information for nineteenth-century Romanian travellers or tourists, as well as for readers in general. Given that few Romanians had the opportunity to travel to the western European countries in the former half of the nineteenth century, his accounts made the European space more accessible to the Romanian people. At the same time, his travels made it possible for him to both learn aspects about other cultures and revive his fondness for his own national origins and identity. Combining features of factual presentation with artistic creation, his accounts also represent a valuable travel text and constitute one of the earliest written accounts of a Romanian traveller to many places in Europe. For Codru-Drăgușanu, the experiencing of other cultures becomes the proper ground for gaining awareness of his own culture's value as well as for making it known worldwide. Moreover, by adopting a protective attitude related to the specificity of his national identity and by developing a discourse of (cultural) difference, he ultimately sought to counteract existing divisions between east and west, whether he did so explicitly or implicitly. 


\section{References and notes:}

Andraş, Carmen. (2003). România si imaginile ei în literatura de călătorie britanică. Un spaţiu de frontieră culturală. Cluj-Napoca, Romania: Dacia.

Andraş, Carmen. (2008). Geografiile simbolice. Iaşi, Romania: Editura Institutul European. Barnes, Julian. (2008). England, England. London, UK: Vintage.

Bauman, Zygmunt. (1998). Tourists and Vagabonds: The Heroes and Victims of Postmodernity. In Postmodernity and Its Discontents. Malden, Massachusetts: Polity Press.

Berindei, Dan. (1989). Călători români paşoptişti. Bucureşti, Romania: Editura SportTurism.

Boorstin, Daniel J. (1992). The Image. A Guide to Pseudo-Events in America. New York, USA: Vintage Books.

Borda, V. (1983). Hronic pe glob. Nouă călători români. București, Romania: Editura Albatros.

Bower, Anne. (1997). Epistolary Responses: The Letter in the 20th-Century American Fiction and Criticism. Tuscaloosa and London, USA \& UK: The University of Alabama Press.

Bracewell, Wendy; Drace-Francis, Alex. (eds.). (2008). Under Eastern Eyes. A Comparative Introduction to East European Travel Writing on Europe. Budapest \& New York, Hungary \& USA: Central European University Press.

Cazimir, Ștefan. (coord.). (1982). Drumuri și zări. Antologie a prozei românești de călătorie. București, Romania: Editura Sport-Turism.

Cmeciu, Camelia-Mihaela; Drugă, Luminiţa. (2011). Romanian Monasteries: Signs of Tourist Attraction and Self-Discovery. In The European Legacy: Toward New Paradigms, 16:6, 751-768.

Codru-Drăgușanu, Ion. (1980). Peregrinul transilvan. 1835-1848. Bucureşti, Romania: Editura Sport-Turism.

Cuddon, J. A. (1999). The Penguin Dictionary of Literary Terms and Literary Theory. Fourth edition, London, UK: Penguin Books.

Culler, Jonathan. (1990). The Semiotics of Tourism. In Framing the Sign: Criticism and Its Institutions. USA: University of Oklahoma Press, retrieved from http://web.mit.edu/allanmc/www/culler1.pdf, March 102014.

Hilt, V. (1972). Călători şi exploratori români. Bucureşti, Romania: Editura Enciclopedică Română.

Holban, Maria. (ed.). (1968-2001). Călători străini despre Țările Române. Volumes I-X, Bucureşti, România: Editura Academiei Române.

Hulme, Peter; Youngs, Tim. (eds.) (2002). The Cambridge Companion to Travel Writing. Cambridge, UK: Cambridge UP.

Iorga, N. (1928). Istoria românilor prin călători. Volumes I-II, second edition, Bucureşti, România: Editura Casei Şcoalelor.

Iorga, N. (1980). Călătorii peste hotare. Volumes I-II, edited and prefaced by Lucian Cursaru, București, România: Editura Minerva.

Iorga, N. (1930). Cum să cetim și să înţelegem arta. Șase conferinţe la Sinaia, August 1930, available at http://upload.wikimedia.org/wikipedia/commons/9/93/Nicolae_Iorga_- 
_Cum_s\%C4\%83_cetim_\%C8\%99i_s\%C4\%83_\%C3\%AEn\%C8\%9Belegem_arta_

-_\%C8\%99ase_conferin\%C8\%9Be_la_Sinaia_(august_1930).pdf.

Kunisch, Richard. (2000). București și Stambul. Schițe din Ungaria, România și Turcia. translated by Viorica Nișcov, București, Romania: Saeculum.

Lăzărescu, Dan A. (1985). Imaginea României prin călători (vol. I, 1716-1789; vol. II, 1789-1821). Bucureşti, Romania: Editura Sport-Turism.

MacCannell, Dean. (1989). The Tourist. A New Theory of the Leisure Class. New York, USA: Shocken Books.

McGirr, Elaine M. (2007). Eighteenth-Century Characters. A Guide to the Literature of the Age. Hampshire and New York, UK \& USA: Palgrave Macmillan.

Mitchell, Sally. (2009). Daily Life in Victorian Britain. Second edition, Westport, Connecticut and London, USA \& UK: Greenwood Press.

Oakland, J. (2011). British Civilization: An Introduction. $7^{\text {th }}$ edition. London, UK: Routledge.

Paterson, Michael. (2008). A Brief History of Life in Victorian Britain. A Social History of Life in Queen Victoria's Reign from the Court to the Slums. London, UK: Constable \& Robinson.

Schulz-Forberg, Hagen. (ed.). (2005). Unravelling Civilisation. European Travel and Travel Writing. Brussels, Belgium: Presses Universitaires Europeenes, Peter Lang S.A.,

Smith, A. D. (1991). National Identity. London, UK: Penguin Books.

Thompson, Carl. (2011). Travel Writing. Taylor \& Francis e-Library.

Vărzaru, Simona. (1984). Prin Țările Române. Călători străini din secolul al XIX-lea. Bucureşti, Romania: Editura Sport-Turism.

Whiter, Walter. (1822). Etymologicon Universale. Vol. II. London, UK: Cambridge University Press.

Youngs, Tim. (ed.). (2006). Travel Writing in the Nineteenth Century. Filling the Blank Spaces. London and New York, UK \& USA: Anthem Press.

http://encyclopedia2.thefreedictionary.com/Whiggamore, accessed October 15, 2014.

http://www.etymonline.com/index.php?, accessed October 15, 2014.

http://www.oxforddictionaries.com/definition/, accessed October 15, 2014. 


\title{
Summary
}

\section{ROMANIAN TRAVELLERS TO ENGLAND IN THE NINETEENTH CENTURY. \\ NATIONAL SPECIFICITY IN ION CODRU-DRĂGUŞANU'S TRAVEL ACCOUNTS}

\author{
Mihaela Culea \\ "Vasile Alecsandri" University of Bacău, Romania \\ Andreia-Irina Suciu \\ "Vasile Alecsandri" University of Bacău, Romania
}

The complexity of the travelling experience cannot be understood outside the scope of culture (see, for instance, Schulz-Forberg 2005) and travelling is thus often discussed in relation to the human being's thirst for knowledge, intellectual or spiritual enlightenment, aesthetic refinement, often as a result of cultural contact, interaction, transfer or exchange. The travelling experiences of Romanian travellers to England through the centuries have been inspired by many of these goals. This paper focuses on the travel accounts of a little known Romanian traveller to England in the nineteenth century, namely, writer, teacher, journalist and politician Ion Codru-Drăgușanu (1818-1884). His travel accounts reveal that travelling was perceived as a source of intellectual improvement, maturation, cultural development, interaction and exchange, as a process of gaining knowledge, an experience also counterbalanced by a tourist's adventure dominated by curiosity, pleasure and amusement. In order to reveal how this shift takes place and the multi-fold significance of the travelling experience as such, the paper's structure combines theoretical data with textual study and seeks to rediscover forgotten personalities of the Romanian culture who made English-Romanian encounters more numerous and productive.

Firstly, the paper presents the conceptual distinctions between the term traveller and other related words, such as voyager, tourist, pilgrim, explorer, or migrant. Secondly, it makes a brief overview of travelling in history and of travel writing with the purpose of contextualizing Codru-Drăgușanu's travels. Thirdly, the synoptic presentation of the literary background related to travels to and from Romania in the nineteenth century as well as the brief review of the historical and cultural context specific to England in that period assist us in our exploration of the written accounts of travels recorded by CodruDrăguşanu in his Peregrinul transilvan. 1835-1848 (The Transylvanian Traveller. 18351848).

Key-words: Travelling, Traveller, Nineteenth-century Romanian travellers, English culture, Cultural contrast 